\title{
FRICTION ANALYSIS ON SCRATCH DEFORMATION MODES OF VISCO-ELASTIC-PLASTIC MATERIALS
}

\author{
Budi Setiyana $^{1 *}$, Imam Syafaat ${ }^{1)}$, Jamari $^{2)}$, and DikJoe Schipper ${ }^{1)}$ \\ ${ }^{1)}$ Laboratory for Surface Technology and Tribology, \\ Faculty of Engineering Technology, University of Twente \\ Drienerloolaan 5, Postbus 217, 7500 AE, Enschede, The Netherlands \\ ${ }^{2)}$ Department of Mechanical Engineering, University of Diponegoro \\ Jl. Prof. Soedharto, Tembalang, Semarang, Indonesia \\ Phone: 024-7460059 ext. 115, Fax: 024-7460059 ext. 102 \\ ${ }^{*}$ Corresponding author: bsetiyana@yahoo.com
}

\begin{abstract}
Understanding of abrasion resistance and associated surfaces deformation mechanisms is of primary importance in materials engineering and design. Instrumented scratch testing has proven to be a useful tool for characterizing the abrasion resistance of materials. Using a conical indenter in a scratch test may result in different deformation modes, like as elastic deformation, ironing, ductile ploughing and cutting. This paper presents the friction analysis of some deformation modes of viscoelastic-plastic behaving polymer materials, especially PEEK (poly ether ether ketone).In general, it is accepted that the friction consist of an adhesion and a deformation component, which can be assumed to be independent to each others. During a scratch test, the friction coefficient is influenced by some parameters, such as the sharpness of indenter, the deformation modes and the degree of elastic recovery. Results show that the adhesion component strongly influences the friction in the elastic and ironing deformation mode (scratching with a blunt cone), friction for the cutting deformation mode (scratching with a sharp cone) is dominantly influenced by the deformation component. From the analysis, it can be concluded that the adhesion friction model is suitable for ironing - elastic deformation mode and the deformation friction model with elastic recovery is good for cutting mode. Moreover, the ductile ploughing mode is combination of the adhesion and plastic deformation friction model.
\end{abstract}

Keywords: adhesion; deformation; friction; scratch

\begin{abstract}
Abstrak
ANALISIS FRIKSI PADA BENTUK DEFORMASI AKIBAT GORESAN PADA MATERIAL VISKO-ELASTIK-PLASTIK. Pemahaman tentang ketahanan abrasi dan deformasi permukaan yang menyertainya merupakan hal yang penting dalam rekayasa dan disain material. Peralatan uji gores terbukti ampuh untuk menyatakan ketahanan abrasi dari material. Pemakaian indenter kerucut dalam uji gores akan menghasilkan beberapa bentuk deformasi seperti halnya deformasi elastik, penyetrikaan, plowing dan pemotongan. Paper ini menyajikan analisis friksi dari beberapa bentuk deformasi permukaan dari material visko-elastik-plastik, khususnya pada PEEK (poly ether ether ketone). Secara umum dinyatakan bahwa friksi terdiri dari komponen adhesi dan deformasi yang diasumsikan tidak bergantung satu sama lain. Selama uji gores, koefisien friksi dipengaruhi oleh beberapa parameter, seperti ketajaman indenter, bentuk deformasi dan pemulihan elastik. Hasil menunjukkan bahwa komponen adhesi sangat berpengaruh pada deformasi elastic dan penyetrikaan (uji gores dengan indenter tumpul), sedang untuk pemotongan (uji gores dengan indenter tajam) sangat dipengaruhi oleh komponen deformasi. Dari analisis dapat disimpulkan bahwa model friksi adhesi cocok untuk deformasi elastic dan penyetrikaan, sedang model friksi deformasi dengan pemulihan elastic, cocok untuk pemotongan. Selain itu, plowing merupakan kombinasi dari model friksi adhesi dan deformasi.
\end{abstract}

Kata kunci: adhesi; deformasi; friksi; gores 


\section{INTRODUCTION}

The scratch resistance of polymer surfaces is very important due to the increasingly use of these materials in industrial application. Due to their low cost, easy in manufacturing and processing and low weight, polymers are more attractive for an increasing number of industries. However, due to poor surface resistance, their lifetime is often limited.

Polymers have visco-elastic-plastic material behavior. Compared to metals and ceramics, polymers exhibit large elastic and visco-elastic deformation to the imposed loading during a scratch test. In scratch tests performed with a single indenter, a groove in the surfaces will be formed. The groove is elastic if just after contacting there is no track visible, visco-elastic if the recovery of the deformed groove is delayed in time, plastic if a groove persists and visco-elasticplastic if a groove persists with partial recovery (Pelletier et al., 2008; Lafaye et al., 2008). Some results are presented in literature of scratch test experiments conducted on polymers, such as polycarbonate, polyethylene, PMMA (poly-methylmethacrylate), PTFE (poly-tetra-fluoro-ethylene), UHMWPE (ultra high molecular weight poly ethylene), PEEK (poly-ether-ether-ketone) (Briscoe, 1998; Briscoe et al., 1996; Ducret et al., 2003; Iqbal et al., 2011).

Some experimental results show a relationship between deformation mode and friction. It will be used as the parameters about the scratch resistance and material hardness. There are two hardness measures that are commonly derived, scratch hardness (also known as normal hardness) and tangential hardness (also called the 'ploughing hardness', 'scratch resistance', or 'ploughing stress', Subhash and Zhang, 2002). In friction theory, Bowden and Tabor (19501954) showed that the macroscopic origin of the friction is due to two mechanisms. The first has a physical origin that is the adhesion of solids, which are sheared and the second has a mechanical origin which is linked to deformation (ploughing) of the solids in contact. Provided that the two mechanisms do not interact on each other, the friction law can be reformulated as the summation of an adhesion term and a ploughing (or deformation) term as (Lafaye et al., 2008),

$$
\mathrm{F}_{\mathrm{t}}=\mathrm{F}_{\mathrm{adh}}+\mathrm{F}_{\text {plough }}
$$

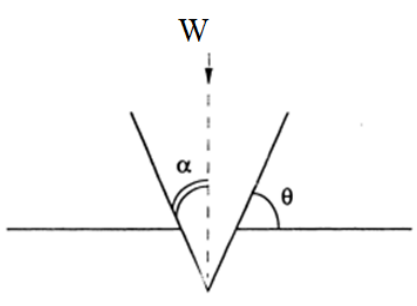

(i)
Subhash and Zhang (2002) studied the adhesion (interfacial) friction in the contact between the surfaces and conical indenter numerically. They showed that the friction by a blunt conical indenter give a high adhesion friction force. Lafaye et al. (2006; 2008) analyzed the ploughing friction model to get an analytical solution. Taking into account elastic recovery, it is concluded that elastic recovery during scratching would decrease the ploughing friction during scratching using a conical indenter, has also been studied analytical and numerically (Felder and Bucaille, 2006).

This paper describes the friction when scratching of visco-elastic-plastic materials. In particular, some experimental results of semicrystalline PEEK (poly-ether-ether-ketone) by Iqbal et al. (2011), are discussed because of its attractiveness for use as high-quality engineering thermoplastic, with very good mechanical properties and excellent high temperature stability (Sinha and Briscoe, 2009).

\section{SCRATCH ON PEEK (POLY-ETHER-ETHER- KETONE) \\ Experimental Results of Iqbal}

Iqbal et al. (2011) conducted scratch experiments on PEEK, poly (ether-ether-ketone) by using conical indenters with different cone angles. Figure 1 shows the schematically material indentation by static indentation (i) and sliding indentation (scratching) (ii) using a conical indenter.

The experiments yielded two scratch deformation modes and transitions between them under different normal loads at room temperature $(20 \circ \mathrm{C})$ and $3 \mathrm{~mm} / \mathrm{s}$ scratching velocity. These results show different scratch deformation modes of PEEK surfaces such as elastic deformation, ironing, ductile ploughing and cutting.

Figure 2 illustrates the correlation of the experimental friction coefficient (the ratio of the tangential force or scratch force over normal load) and the type of surface deformations observed after scratching for variable normal loads and conical indenters. The scratch maps were constructed using the nominal contact strain and the measured friction coefficient. The nominal contact strain in case of indentation, for conical indenters, has been defined by Tabor et al. (1950-1954) as,

$$
\varepsilon=\mathrm{k} \tan \alpha
$$

Figure 1. Contact between a conical indenter and a surface (i) static indentation (ii) sliding indentation (Briscoe, 1998). 
where, $\mathrm{k} \approx 0.2$ for work hardening metal surfaces. Briscoe and coworkers have argued that although the constant is slightly lower in magnitude for polymers, the same value may be applicable these materials. The measured friction coefficient in the elastic and ironing deformation regions was higher than the predicted theoretical one by Bowden and Tabor (1950-1954) which is represented by straight line.

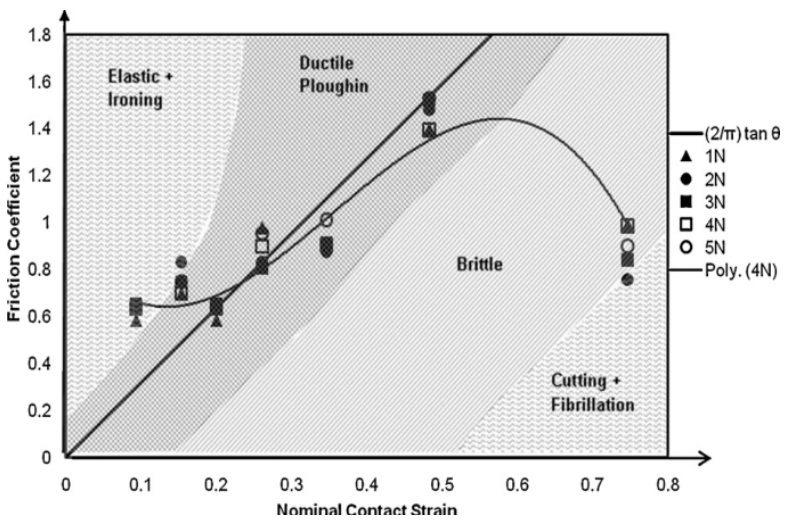

Figure 2. Friction mode map of semi crystalline PEEK. The plot shows the deformation modes and the dependence of the friction during scratching of the PEEK on contact strain and normal load (Iqbal et al., 2011).

\section{Friction Model Application on Scratching Deformation of PEEK}

Felder and Bucaille (2006) argued that sliding indentation (scratching) accompanied by elastic recovery as shown in Figure 3.

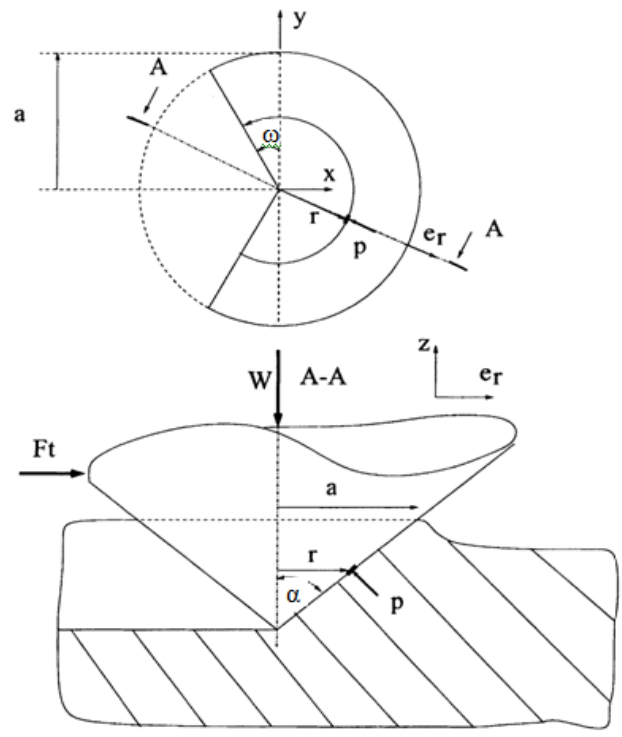

Figure 3. Schematic representation of scratch which is accompanied by elastic recovery, show on top view and cross section A-A (Felder and Bucaille, 2006).

The friction force, $\mathrm{F}_{\mathrm{t}}$ at sliding indentation work against the moving direction (horizontal), therefore the vertical hardness during sliding contact is assumed not to be included in the friction force and they developed the equation as,

$$
H_{v}=\frac{W}{a^{2}\left(\frac{\pi}{2}+\omega\right)}=p_{m}
$$

Based on Figure 3, equation (1) and (3) one, can derive the friction force during scratching as,

$$
F_{t}=\mu_{a d h} p_{m} a^{2}\left(\omega+\frac{\pi}{2}\right)+p_{m} a^{2} \cot \alpha \sin \left(\omega+\frac{\pi}{2}\right)(4)
$$

From the above equation, the scratch resistance or scratch hardness $\mathrm{H}_{t}$ is defined as the friction force divided by projected ploughing area $\left(\mathrm{a}^{2} \cot \alpha\right)$,

$$
H_{t}=\mu_{a d h} p_{m}\left(\omega+\frac{\pi}{2}\right) \tan \alpha+p_{m} \sin \left(\omega+\frac{\pi}{2}\right)
$$

The overall friction coefficient $\mu$ is defined by dividing the friction force $\mathrm{F}_{\mathrm{t}}$ with the load $\mathrm{W}$,

$$
\mu=\mu_{a d h}+\left(\frac{\sin (\omega+\pi / 2)}{\omega+\pi / 2}\right) \cot \alpha
$$

Using a blunt conical indenter for scratching cause elastic deformation and the deformed surfaces will recover instantaneously. Due to its geometry, it will give a small value of $\cot \alpha$ and a large contact area, therefore it cause a low contact pressure. In this case, there is no mass transferred to the sides of the groove and the friction force is adhesion friction due to interfacial friction only. In this case, the surface recovers instantaneously, i. e. $\omega=\pi / 2$. Equation (4) simplifies to,

$$
F_{t}=\mu_{\text {int }} p_{m} \pi a^{2}
$$

A higher deformation by a blunt cone results in the ironing mode in which the elastic recovery of the material surface need time after the blunt cone has passed. In this deformation mode, the visco-elastic material behavior is of importance. Using a hard spherical indenter, Flores et al. (2008) proved that the interfacial friction coefficient in the elastic deformation mode is rather constant.

Ploughing the general mode of surface deformation in which the friction is described with (6), and in this mode, the adhesion friction is contributed by shear ploughing $\left(\mu_{a d h}=\mu_{\text {shear }}\right)$. The value of the friction coefficient due to shear ploughing is depending on the shear strength of the material. The straight line in Figure 2which has been proposed by Bowden and Tabor, represent the ploughing friction coefficient which is assumed as a purely plastic deforming material $(\omega=0)$ and the friction coefficient becomes,

$$
\mu=\frac{2}{\pi} \cot \alpha
$$

Figure 2 shows that the friction coefficient at the left side of that line (scratching with a blunter indenter) is higher than equation (8) and on the right side (scratching with a sharp indenter) the friction coefficient is lower due to the elastic recovery of deformed material. 
In the cutting mode, the nominal contact strain is high and the indenter is sharp, therefore it gives a narrow scratch. The narrow scratch gives a small deformation and apart of deformed material is still in elastic condition. Therefore, a part of material deformed at groove side turn back to the rear face of the indenter and give high rear angle. It will give a high elastic recovery and ploughing friction coefficient at equation (6) become small, which is shown at Figure 2.

\section{RESULTS AND DISCUSSIONS}

Iqbal and Bucaille (2006) made an approximation for the friction coefficient (Figure 2) by a polynomial curve fit. Although this fitting result give a good correlation with the experimental results, it is very difficult to understand the physical and mechanical phenomena behind it.

Referring to Figure 2 and equation (6), it can be seen that in the adhesion mode, the interfacial friction coefficient is around to 0.6. In the ploughing and the cutting mode, there are two unknown parameters, namely the friction coefficient due to shear ploughing $\mu_{\text {shear }}$ and the rear angle $\omega$. By adjusting these parameters, a based on equation (6) and the experimental results (Figure 2) can be made. Figure 4 shows the result of the analysis.

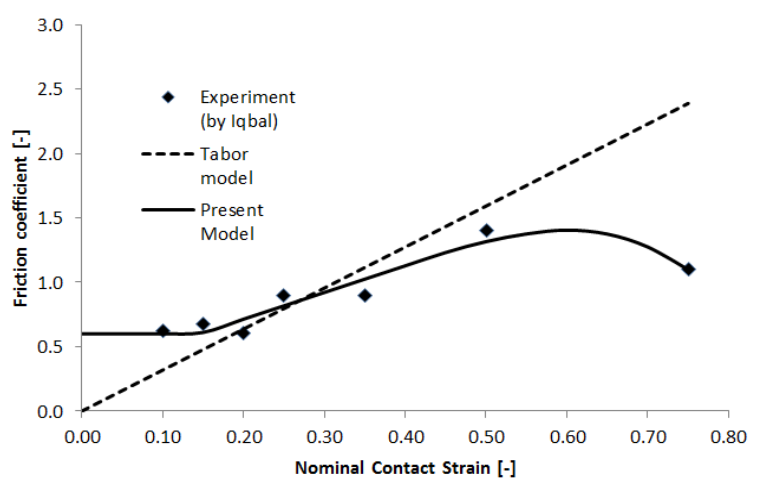

Figure 4. The friction coefficient as function of a nominal contact strain, experimental results PEEK (Iqbal et al., 2011), Tabor theory, Eq. (8) and the present model, Eq. (6).
In the analysis various values of the shear friction coefficient of the material of $0.1,0.2,0.3$ and 0.4 were used to obtain values for the rear angle $\omega$. Figure 5 show the relation between the rear angle, nominal contact strain (determined by $\alpha$ ) and shear friction coefficient $\mu_{\text {shear. }}$

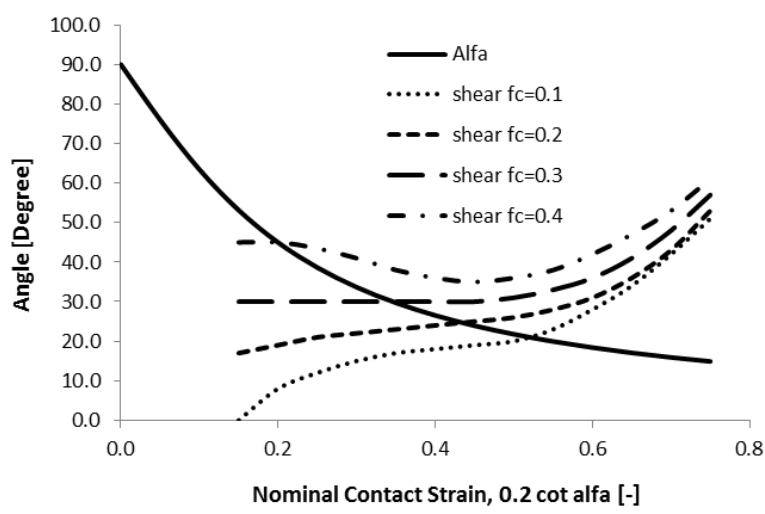

Figure 5. The relationship between the rear angle and nominal contact strain $(0.2 \cot \alpha)$ for different values of the shear friction coefficient. (shear $\mathrm{fc}=$ shear friction coefficient).

Pelletier et al. (2008) performed in situ observation of the rear angle due to elastic recovery by scratching PMMA using a pin with a spherical tip with a radius of $116 \mu \mathrm{m}$. Elastic recovery occurred at low depths. Figure 6 shows a reproduction of the experimental observations of Pelletier, i. e. angle $\beta$ and rear angle.

Although direct comparison between Figure 5 and Figure 6 is difficult, however it shows that a rather constant value of rear angle at ploughing mode of both above figures. Figure 6 shows that at transition regime between adhesion mode and ploughing mode, the rear angle increase from constant value at the ploughing to the adhesion mode. Further, it can be seen that there is no constant value of rear angle at a friction coefficient of 0.4 , therefore a suitable value of shear friction coefficient is about 0.3 .

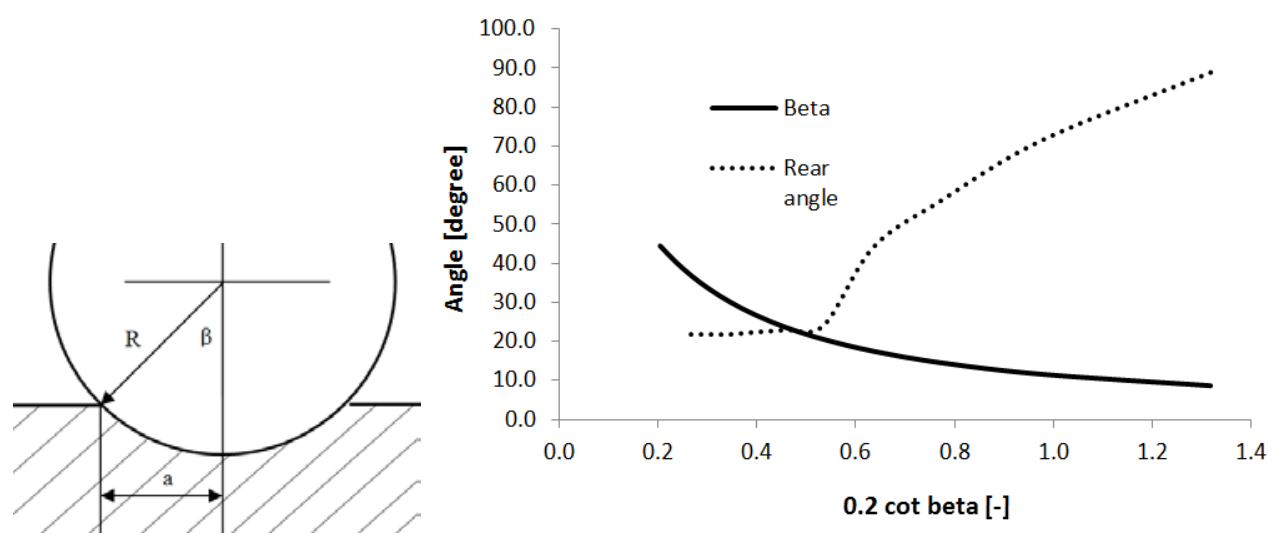

Figure 6. Relationship between rear angle and angle $\beta$, during scratching of PMMA by a spherical indenter, after Pelletier (Sinha et al., 2009). 


\section{CONCLUSION}

During a scratch test, the friction coefficient is influenced by some parameters, such as the sharpness of the conical indenter, the deformation modes and the degree of elastic recovery. In this paper, a general friction model is presented for scratching of viscoelastic-plastic material.

The results show that an adhesion models is suitable for the elastic and the ironing deformation mode (scratching a blunt cone) and that the friction coefficient is rather constant. There is no mass transfer along the sliding indentation and the deformed surface recover to the initial form instantaneously (elastic) or with a delay in time (ironing). The friction model for the ductile ploughing deformation mode is a combination of adhesion (shear ploughing) and deformation with low elastic recovery. An increase of the attack angle will increase the deformation friction coefficient. Moreover, the cutting deformation mode (scratching with a sharp cone) is a combination of adhesion and deformation with high elastic recovery. Scratching a sharp cone give a narrow groove and cause the deformed material at groove side turn to rear face of the indenter due to elastic recovery. Analyzing by proposed friction model gives the predicted value of shear ploughing friction coefficient with some rear angle value due to elastic recovery effect.

\section{ACKNOWLEDGEMENT}

The authors would like to thanks the Department of Education and Culture Indonesia, especially the General Directorate of Higher Education for the scholarship and valuable support during this research.

\section{NOMENCLATURE}

$\alpha=$ semi apical angle of conical indenter, deg

$\beta=$ semi contact angle of spherical indenter, deg

$\varepsilon=$ nominal contact strain

$\theta \quad=$ attack angle, deg

$\mu \quad=$ overall friction coefficient

$\mu_{\mathrm{adh}}=$ adhesion friction coefficient

$\mu_{\text {int }} \quad=$ interfacial friction coefficient

$\mu_{\text {plough }}=$ ploughing friction coefficient

$\mu_{\text {shear }}=$ shear friction coefficient

$\omega=$ rear angle, deg

$\mathrm{a}=$ contact radius, $\mathrm{mm}$

$\mathrm{d}=$ contact diameter, $\mathrm{mm}$

$\mathrm{F}_{\mathrm{t}} \quad=$ tangential force, $\mathrm{N}$

$\mathrm{F}_{\text {adh }}=$ adhesion force, $\mathrm{N}$

$\mathrm{F}_{\text {plough }}=$ ploughing force, $\mathrm{N}$

$\mathrm{H}_{\mathrm{v}}=$ vertical hardness, $\mathrm{Nm}^{-2}$

$\mathrm{H}_{\mathrm{t}}=$ tangential hardness, $\mathrm{Nm}^{-2}$

$\mathrm{p}=$ pressure, $\mathrm{Nm}^{-2}$

$\mathrm{p}_{\mathrm{m}}=$ mean pressure, $\mathrm{Nm}^{-2}$

$\mathrm{R}=$ sphere radius, $\mathrm{mm}$

$\mathrm{W}=$ vertical load, $\mathrm{N}$

\section{REFERENCES}

Bowden, F.P. and Tabor, D., (1950-1954), The Friction and Lubrication of Solids, Vol. I, Clarendon Press, Oxford, UK.

Briscoe, B.J., (1998), Isolated Contact Stress Deformation of Polymers: The Basis for Interpreting Polymer Tribology, Tribol. Int., 31, pp. 121-126.

Briscoe, B.J., Evans, P.D., Pelillo, E. andSinha, S.K., (1996), Scratching Maps for Polymers, Wear, 200, pp. 137-147.

Briscoe, B.J., Pelillo, E. and Sinha, S.K., (1996), Scratch Hardness and deformation Maps for Polycarbonate and Polyethylene, Polym. Eng. Sci., 36, pp. 2996-3005.

Ducret, S., Mattei, C.P., Jardret, V., Vargiolu, R. and Zahouani, H., (2003), Friction Characterization of Polymers Abrasion (UHWMPE) During Scratch Test: Single and Multi-Asperity Contact, Wear, 255, pp. 1093-1100.

Felder, E. and Bucaille, J.L., (2006), Mechanical Analysis of The Scratching of Metals and Polymers with Conical Indenters at Moderate and Large Strains, Tribol. Int., 39, pp. 70-87.

Flores, S.E., Pontin, M.G. and Zok, F.W., (2008), Scratching of Elastic/Plastic Materials with Hard Spherical Indenters, J. Appl. Mech., 75,pp. 061021$1-7$.

Iqbal, T., Briscoe, B.J. and Luckham, P.F., (2011), Scratch Deformations of Poly (ether ether ketone), Wear, 271, pp. 1181-1193.

Lafaye, S., (2008), True Solution of The Ploughing Friction Coefficient with Elastic Recovery in The Case of a Conical Tip with a Blunted Spherical Extremity, Wear, 264, pp. 550-554.

Lafaye, S., Gauthier, C., and Schirrer, R., (2008), Analyzing Friction and Scratch Test without in situ Observation, Wear, 265, pp. 664-673.

Lafaye, S. and Troyon, M., (2006), On The Friction Behavior in Nano-Scratch Testing, Wear, 261, pp. 905-913.

Pelletier, H., Durier, A., Gauthier, C. and Schrirrer, C., (2008), Visco elastic and Elastic-plastic Behaviors of Amorphous Polymeric Surfaces During Scratch, Tribol. Int., 41, pp. 975-984.

Sinha, S.K. and Briscoe, B.J., (2009), Polymer Tribology, Imperial College, Press, pp. 108-140

Subhash, G. and Zhang, W., (2002), Investigation of Overall Friction Coefficient in Single-pass Scratch Test, Wear, 252, pp. 123-134. 